\title{
Belphégor
}

\section{Literary Lessons. Knowledge and Genre in Dutch Middlebrow Fiction of the Interwar Years}

\section{Bram Lambrecht, Pieter Verstraeten and Dirk de Geest}

\section{(2) OpenEdition}

\section{Journals}

\section{Electronic version}

URL: http://journals.openedition.org/belphegor/922

DOI: 10.4000/belphegor.922

ISSN: 1499-7185

Publisher

LPCM

\section{Electronic reference}

Bram Lambrecht, Pieter Verstraeten and Dirk de Geest, « Literary Lessons. Knowledge and Genre in Dutch Middlebrow Fiction of the Interwar Years », Belphégor [Online], 15-2 | 2017, Online since 28 November 2017, connection on 20 April 2019. URL : http://journals.openedition.org/belphegor/922 ; DOI : 10.4000/belphegor.922

This text was automatically generated on 20 April 2019.

\section{$\Theta \Theta \Theta \Theta$}

Belphégor est mis à disposition selon les termes de la Licence Creative Commons Attribution - Pas d'Utilisation Commerciale - Pas de Modification 4.0 International. 


\title{
Literary Lessons. Knowledge and Genre in Dutch Middlebrow Fiction of the Interwar Years
}

\author{
Bram Lambrecht, Pieter Verstraeten and Dirk de Geest
}

1 It has become a commonplace to characterize interwar middlebrow literature by its adherence to the age-old dictum of utile dulci. Indeed, middlebrow fiction is believed to owe its popularity not only to its high entertainment value, but also to its pedagogical or didactic function. The terms by which this pedagogical function has been designated, however, differ significantly. Nicola Humble for instance considers the 'middlebrow novel [...] as a form of conduct literature, educating lower-middle-class readers in the rules of haute-bourgeois discourse and behavior.' ${ }^{1}$ Jennifer Shepherd, in her article on fin-de-siècle middlebrow feminism, identifies the 'developing middlebrow cultural formation at the end of the nineteenth century [...] by its commitment to popularizing fiction as an instrument of social pedagogy'. ${ }^{2}$ For Janice Radway, one of the paradoxical essences of 'what became known as middlebrow culture' is its combination of modern 'periodicity and marketing strategies' with 'an older, Arnoldian understanding of culture as a spiritual guide and source of moral instruction'. ${ }^{3}$ In this sense, Radway embroiders on Joan Shelley Rubin's influential book The Making of Middlebrow Culture, in which the genteel tradition of Matthew Arnold is considered to be a crucial basis of the American middlebrow culture from the 1920 s to the 1940 s. $^{4}$ These examples illustrate that the allegedly pedagogical role of middlebrow literature can vary from the transmission of moral principles, over rules of social behavior to life style instructions and the transfer of a certain savoir-vivre. The great variety of phenomena brought together under the header of middlebrow's pedagogical function shows the need for a more consistent and systematic terminological frame, capable of describing the different kinds of knowledge involved. Moreover, generally, scholarly explorations into the domain of the middlebrow novel (Humble, Shepherd) mainly confine themselves to an analysis of literary themes and motives, leaving the narratological and rhetorical devices of a discursive transfer of knowledge outside their scope. 
2 A second commonplace in middlebrow studies is to suggest that the notion of 'middlebrow literature', rather than demarcating a well-defined and recognizable literary genre, functions (or should function) as a supra-generic label, regrouping various middlebrow subgenres. In the introduction to The Masculine Middlebrow for example, which aims at a broader understanding of the concept, Kate Macdonald considers the crime novel, the girls' school story, the detective fiction and the thriller as genuine 'middlebrow genres'. ${ }^{5}$ Macdonald's list can be elaborated with the enumeration of genres in Humble's introductory chapter: 'the middlebrow is a hybrid form, comprising a number of genres, from the romance and country-house novel, through domestic and family narratives to detective and children's literature and the adolescent Bildungsroman' ${ }^{6}$ . At the same time, however, middlebrow scholars rarely really adopt such an inclusive approach and stick close to the narrow conception of middlebrow literature as the mere 'body of work that inhabits, epitomizes, and anatomizes middle-class English social mores' and that was 'for the most part written by women and aimed at a female readership' - the bourgeois ladies' novel. ${ }^{7}$ The generic hybridity and complexity of middlebrow literature in the interwar period, let alone its generic evolutions or even the correlation between pedagogical function and generic identity, consequently remains unexplored.

3 Hence, the aim of this paper is to bring together these two perspectives - the functionalist and the generic - to explore the following questions : by which narrative and rhetorical strategies does a middlebrow novel construct and pass on various types of knowledge? Which specific and different types of knowledge can one discern? And, eventually, what is the relationship between the generic form of a novel and the types of knowledge it hands on? These overall questions will inform our reading of two bestselling Dutch-language novels of the interwar period: the regional novel Whitey (De Witte, 1920) by the Flemish internationally bestselling author Ernest Claes $^{8}$ and the colonial novel Rubber (1931) by the Dutch female novelist Madelon Székely-Lulofs. ${ }^{9}$

4 If we broaden the scope of the concept of the middlebrow, in order to comprise a wide 'range of activities aimed at making literature and other forms of 'high' culture available to a wide reading public', ${ }^{10}$ both Whitey and Rubber can be seen as manifestations of an upcoming middlebrow culture in the interwar literary context in Flanders (the Dutch speaking part of Belgium) and the Netherlands. ${ }^{11}$ The novels by Claes and Székely-Lulofs, like many others of their sort, enjoyed enormous popularity. Their content as well as their form seemed to be designed to appeal to the widest audience : both novels borrow from very popular genres of the time (the regional and the colonial 'Indian' novel); they stick to a realistic mode of writing that is in some ways reminiscent of nineteenthcentury realism, but is also to different degrees adapted to a new literary and social context, adopting moderately 'modern' ingredients and techniques.

Claes's novel Whitey was a major public success and became an instant classic. During the author's lifetime it was reprinted more than one hundred times, in 1934 it was turned into an equally popular movie, and it was even distributed by a chocolate factory as a set of collectible stickers. The title refers to the nickname of the young hero Louis, the main character in the book, who is called 'Whitey' (De Witte) by the local community because of his very blonde hair. The novel consists of a series of humorous anecdotes taken from the young life of the protagonist. They recount the pranks he plays on the people in a small rural Flemish community. Most of them revolve around the conflicts between the non-conformist child Whitey and the adults, who want to correct his wayward ways and 
to maintain law and order. Although Whitey is an incorrigible rogue, his tricks are harmless and the world depicted by Claes is that of a rural idyll, untainted by the problems of modern life. (Undoubtedly, some of the popularity of the book derived from the marked contrast between this kind of unproblematic, clearly fictitious world and the horrors of the First World War, experienced by Claes himself and documented in some of his writings of the same period.)

When some ten years later, in 1931, the novel Rubber by Madelon Székely-Lulofs appeared, it became an instant bestseller too, with several reprints and translations in 12 languages during the $1930 \mathrm{~s} .{ }^{12}$ The title was adapted to the screen soon after its publication (in 1936). Part of the success of the book may be explained by the scandalous content, as it discloses the abuses of the colonial exploitation of Sumatra and the decadent and licentious life of the planters just before the economic crisis of 1929. At a first glance, Székely-Lulof's novel diverges significantly from Whitey. Except for a brief scene in Holland, Rubber is set in an exotic geographical region at the east coast of Sumatra, one of the former colonies of the Netherlands. The book depicts the life of the so-called 'planters', Dutch fortune hunters who try to achieve promotion and accumulate wealth in the hierarchically structured rubber companies in the East Indies. In the eyes of Székely-Lulofs, their existence is marked by hard, risky and often fruitless work, but also by prodigality, extreme alcoholic escapades, sex, and adultery. Some of the descriptions of this kind of life in the East clearly transgressed the boundaries of what was socially (and aesthetically) accepted in the (Christian and bourgeois) Low Countries at the time. ${ }^{13}$

7 In short, whereas these books can be seen as typical instances of middlebrow fiction with a high popular appeal, intended for a broad public, well suited for cross-media adaptations, there are considerable differences too. While Whitey offers a picturesque sketch of idyllic and traditional life in the Flemish countryside, Rubber unmasks the colonial exploitation of a far off exotic region as an exponent of a flawed world economic system and reveals the moral decadence of the people involved. As such, the two cases illustrate the generic variety in middlebrow fiction, which constitutes an ideal starting point for our exploration of the multifaceted nature of pedagogy in the middlebrow novel.

\section{Middlebrow, pedagogy and knowledge}

8 In order to unravel the pedagogical function of the middlebrow novel, it may be useful to situate this function vis-à-vis other 'functions' or 'uses' that are usually attributed to literary discourse. In our view, middlebrow literature is constantly trying to find a balance between at least three literary functions, viz. the aesthetic function as such, the function of entertainment, and the pedagogical or didactic function. The idea that literature combines beauty, pleasure and learning, however, has a long history, that can even be traced back to antiquity - think of Horace's already mentioned dictum of utile dulci-, and is by no means specific enough to characterize a particular genre or subgenre in a particular historical period. Still, the rise of the notion of a pure aesthetic in the eighteenth century, ${ }^{14}$ the emergence of autonomous conceptions of literature in the nineteenth century, and the culmination of such tendencies in certain modernist poetics in the early twentieth century have undoubtedly led to a reconfiguration of the abovementioned literary functions. This reconfiguration can be understood as a form of hierarchization, by which the aesthetic function has become dominant and the other 
functions are reinterpreted in relation to the prevailing ideas of literary autonomy. This does not imply that the realist or modernist novel, to name but two examples, do not (aim to) offer moments of pleasure or of learning; yet it does mean that the functions of entertainment and of pedagogy, which had always been part of the literary experience, are reinterpreted according to the artistic project of a realist/modernist poetics. In contrast to the more legitimate and highbrow novelistic forms, this hierarchization of literary functions is less outspoken in the middlebrow novel. Conversely, as far as middlebrow fiction is concerned, the importance of the pedagogical function does not imply that the aesthetic function is discarded altogether. In our opinion, the position of middlebrow literature with regard to this tension between autonomy and heteronomy inevitably entails a sort of double bind. On the one hand it aspires to beauty and wants to be regarded (and evaluated) as genuine literature. On the other hand, middlebrow literature does not strive towards art for art's sake, as it focuses on life, not as an abstract universal but in its specific everyday shape, with its concrete, even practical problems and issues, and with its pleasures too.

9 Next to a relational definition of the pedagogical function, which situates the pedagogy of the novel with regard to other literary functions, it is important to zoom in on the idea of a literary pedagogy in itself. Central to the understanding of the pedagogical function is the notion of knowledge. The relation between knowledge and literature has been studied from different angles and perspectives (the relation between science and literature, literature's claims to 'truth', the problem of literary mimesis, etc.), ${ }^{15}$ yet generally this massive body of work usually speaks of both 'knowledge' and 'literature' in very general and abstract terms. In contrast, Rita Felski argues in a chapter on knowledge in Uses of Literature that 'much will depend on how we define the act of knowing'. ${ }^{16}$ From this perspective, the central issue is not so much whether literature can or cannot provide real knowledge of the world; more crucial is the question of what specific kinds of knowledge literature has on offer. This question is, Felski argues, related to the notion of genre, as 'knowledge and genre are inescapably intertwined, if only because all forms of knowing - whether poetic or political, exquisitely lyrical or numbingly matter-of-fact rely on an array of formal resources, stylistic conventions, and conceptual schemata'. ${ }^{17}$

10 This is precisely the line of thought we want to pursue in the following paragraphs, by focusing on two middlebrow novels, respectively exemplifying the rural novel and the colonial novel, on the types of lessons they contain and on the formal narrative and rhetorical strategies that are deployed to disseminate knowledge. Our conception of 'literary knowledge', as will become clear, will be as inclusive as possible (without restricting literary knowledge to social learning, as it is often done in middlebrow studies), but will necessarily remain a bit exploratory and schematic too in its aim to provide building blocks for a more systematic account of the various forms of learning in the novel. Further, we conceive the literary transfer of knowledge as a process which occurs on two levels: on the intradiegetic level (the acquisition of knowledge by the characters) and the extradiegetic level (the transfer of knowledge as a negotiation between the narrator and the reader). Both levels, however, are intrinsically interrelated.

11 Before we start our analysis, one final remark has to be made. Although knowledge is essential to any kind of pedagogy, these notions do not coincide. As a result, considering knowledge from the perspective of pedagogy has important consequences. First, in contrast to lots of modernist novels from the same period, the novels which will be discussed here are not so much concerned with epistemological issues (i.e. the theory of 
knowledge), as with the pragmatics of knowledge, with knowledge that is socially embodied. Second, as pedagogy is always a process rather than a state of affairs, knowledge is presented as something dynamic, something that can for instance be acquired, or can develop, rather than as a given set of ideas or truths.

\section{Ernest Claes's Whitey : the regional}

12 Our first case study, Ernest Claes's novel Whitey (1920), is one of the most famous instances of the so-called regionalist genre in Flanders, ${ }^{18}$ which enjoyed its heyday from the late nineteenth century until the Second World War. This boom of regional literature was not restricted to the Dutch-language area but also characterized the literary production of other countries in Western Europe as well as the United States. ${ }^{19}$ Despite its omnipresence, high popularity and key role in the literary history of the period, the regionalist genre has not really been taken into account in middlebrow studies, although Nicola Humble considers 'the country-house novel' as one of the many middlebrow genres. ${ }^{20}$ In a chapter on landscape and wilderness in Canadian middlebrow fiction, Amy Tector has made an effort to broaden the generic scope of the middlebrow novel towards the regional..$^{21}$ The question arises as to how the typical generic features influence the types of knowledge and the ways in which these are transferred.

The pedagogical purport of Whitey can be situated on two levels. On the one hand, despite the frequent internal focalization, the extra- and heterodiegetic narrator of the story remains in the foreground and instructs the reader explicitly. The transfer of knowledge then takes place between the auctorial narrator and the reader. On the other hand, the novel functions as a fragmentary Bildungsroman and thus describes the learning process of Whitey, who goes to school, listens to authoritarian figures such as his mother, his father, the teacher and the priest, and learns how to live and to behave by trial and error. Sometimes Whitey's insights and lessons are made explicit by the narrating voice, at other times his learning process and his personal reflections upon it serve as a subtle example or even exemplum for the reader.

As is the case with almost any regionalist novel, Claes's novel Whitey has both a documentary and an encyclopedic function. The novel documents life in a well-defined geographical area within a more or less defined historical frame. Such a documentary intention fits in with the somewhat conservative aspirations of many regional writers, who aim at preserving for the future a rural identity which threatens to be lost in modern times of urbanization and industrialization. ${ }^{22}$ Claes combines this documentary ambition with encyclopedic information about the region, its history, language and folklore. Whitey is composed of fourteen anecdotal chapters, in which the constant circulation of the protagonist serves as a textual device for mapping out in detail a rural Belgian village, Zichem. Whitey visits cultural realms such as the railway station, the school, the church, the mansion of the landlord, the local grocery or the inn, but he discovers natural zones as well, such as the riverside, the fields or the wood. In this way, the wanderings of the protagonist offer an almost synthetic view of a village in the countryside. Moreover, the author localizes Whitey's journeys by means of concrete and factual toponyms: the multiple mentions of names of streets and surrounding hamlets make it possible, even today, to situate the events on a map. The circulation of the protagonist guides the auctorial descriptions, which render the documentary function of the novel even more manifest. Descriptions help the writer to represent inside and outside spaces, folkloristic 
events and typically agrarian activities. In the following passage, for instance, the narrator - via the focalization of Whitey - describes the actions of a miller and for that end uses the appropriate jargon :

Just before the bridge over [the river] the Kleine Demer he stopped. At the mill just over the bridge they were busy lifting sacks of corn into the loft on a long rope running over a pulley fastened in front of the window. Whitey was already well informed as to how the bulging sacks could be hauled up in a jiffy without apparent difficulty, for it was well known that a small boy was needed to turn the large wheel in the loft which drew the rope over the pulley (62).

The narrator even uses real 'documents'; for instance, he cites full folk songs about important eras of the national or regional history. Such documentary passages are often combined with explicit encyclopedic information, often formulated in a gnomic present tense. For instance, describing the 'rocky promontory' of the local wood, the narrator adds that it is the place 'where, according to the old Zichem legend, the Hussites had once lived' (117). Next to concrete geographical, historical and folkloristic information, the regionalist text also documents, and explains, the dialect of the region. In the Dutch version of the novel, there is an important discrepancy between the text of the narrator in the Dutch standard language - and the words spoken by the characters - mainly in dialect. Again, the mere documentation of dialectal terms and phrases goes hand in hand with a moment of instruction : the narrator often clarifies the meaning of such regional terms, for instance by means of mentioning a more common synonym or of giving a paraphrase. ${ }^{23}$ Such explanations of words enable the (non-local) reader not only to enjoy the couleur locale without losing the meaning of certain passages but also to gain insight into an unfamiliar region and language.

The encyclopedic function even becomes one of the main themes of Claes's novel. The issue of education is frequently reflected upon in Whitey. Many scenes take place in a school setting and are literal transcriptions of the teacher's courses about, amongst other subjects, mathematics, national history, or poetry. To a certain extent, such flows of explicit 'school manual knowledge' appeal to a sense of recognition by contemporary readers, who have all passed through a similar, uniform education. Moreover, such scenes constitute a critique of the principle of an almost mechanical reproduction of knowledge upon which traditional education is based. Like so many children, Whitey hates going to school and he is convinced that the kind of knowledge imposed on himself and his fellow pupils is nonsense and utterly pointless, and the narrator seems to endorse his conviction: 'So Whitey was bored with school. Every day catechism, arithmetic, history, geography, and so on, and everything taught in a way specially designed, it seemed, to put young children - and they did not have to be like Whitey by a long chalk - off these subjects for the rest of their lives' (12). Throughout the entire novel institutionalized forms of learning are depicted as dreary and unproductive activities, which are sharply contrasted to the vitality of living nature. In this sense, it is highly symbolical that the narrator describes the classroom as a rigidly closed space, opposed to nature, the realm of freedom :

[Whitey] gazed through the window at the wide, blue, glorious sky above a sunny world in which everything rejoiced and exulted in summer gladness. [...] With its bare, bald walls, devoid of anything pleasing to the eye, the schoolroom seemed to him something apart from the world as he knew it, something crude and cold, out of time. The sunshine never penetrated inside, and the outer window-panes were made of frosted glass, to make sure of shutting out all the life outside. During playtime the class-room door stood ajar, but no window was ever opened (24). 

encyclopedias, and in school, it also hints at types of knowing and trajectories of learning of another order, which are less theoretical and more practical, which are the result of personal experience, rather than authoritative teaching. discursive space, they also show the social hierarchy of an interwar village - to the protagonist as well as to the reader. Whitey visits the prominent citizens of his hometown, such as the priest and the landlord, but he enters into contact too with vagabonds and the children who live 'behind the Sand-hills', the poor area of the village (89). His parents do not want him to play with these children, who are considered as 'scamps'. Whitey's adventurous circulation through discursive space consequently guides his social formation too. His visit to the house of Mister Boon, the landlord, is significant in this respect. After his mother's order 'to mind his manners when he went to Mijnheer Boon's' (36), Whitey leaves and soon arrives at the landlord's mansion :

Jesus! What a room it was! The whole floor was covered with something like velvet, but much more delicate and softer than the velvet cord they made trousers with, and with all manner of little flowers woven into it. [...] Over by the fireplace there was a huge mirror reaching to the ceiling. How daft! Who could look in it, way up there? (43)

The confrontation with the interior domestic spaces of upper-class people triggers a sense of amazement, although the subversive view of the childish protagonist also ridicules mister Boon's objects of distinction. Whitey doesn't consider the big mirror as an aesthetic but as an impractical thing. Next to the personal encounters of the protagonist with upper-class characters, public scenes too play a crucial role in the revelation of social hierarchies and in the illustration of possible ways of handling them. In the inn, the railway station or the church, for example, characters of several social classes interact with each other and as a result form a model or an anti-model for the reader (e.g. p. 189-191, 202-203). On top of this class consciousness and social behavior, Whitey is also initiated into the rules of lifestyle and of running a household. His mother obliges him to help cooking, babysitting, or doing the shopping - all 'girlish' activities which prevent him from experiencing adventure in nature.

Whitey's formation, both in school and at home, is also a moral Bildung. Interestingly, the transmission of moral knowledge happens in an institutionalized fashion similar to the transmission of pure encyclopedic information. The teacher, the priest and Whitey's parents seem to consider morality as a theoretical rather than as a practical type of knowledge. For instance, the protagonist is compelled to learn the works of charity by heart, without really understanding their profound meaning or practical consequences. Internalizing the works of charity is reduced to merely memorizing them (22). However, Whitey's actual moral coming-of-age does not depend on the official religious and moral instruction, but on lived experience (lessons of life for life) and imagination. Such moments of experiential insight are legion, but the following passage may be considered as the most crucial one in the novel. Whitey falls asleep in a meadow, and flora and fauna come to life :

Around the sleeping boy all the beautiful things of nature kept watch, and sang of Life.

'Whitey,' sang the scarlet gilly-flowers, the blue forget-me-nots, the white daisies, the purple clovers and the violet cuckoo-flowers. 'White-haired boy, rest and sleep in the myriad hues and scents of summer...' 
'Whitey,' sang the lowly spear grass, the yellow rattle, the plantain and thistle, the sedge and the iris ; 'it's only springtime once, it's only summer once...'

'Whitye,' chirped the cricket on the sorrel leaf ; 'grown-ups know nothing of this... one is only nine years old once... and the song is soon over.' (101-102)

21 Whereas moral instruction at school, at home or in church appears to be unsuccessful, only an intense and empathetic contact with nature - an essential theme in regional literature - reveals the real values in life. This lesson by nature, created in Whitey's dreams and imagination, bears the mark of an ultimate (and divine) authority, since 'all the little flowers and all the tiny creatures, all that grows and blooms and lives unseen and unbeknown' are all components of 'God's sunny world' (102). As the above citation illustrates, the moral formation of the protagonist through imagination and experience in nature is often translated into gnomic formulas, thus linking the intradiegetic with the extradiegetic level and stressing the general importance of Whitey's personal moral insight.

A final type of knowledge is what we would call artistic competence. Middlebrow literature, it is often said, not only aims at functioning as genuine, aesthetically valuable literature, but also serves to introduce the average reader into the world of art and literature. In the case of Whitey, the several descriptive passages, a typical feature of early-twentieth-century literature in general and of regional literature in particular, ${ }^{24}$ fulfill the aesthetic function of the text. In such aesthetic descriptions, the author uses all the ingredients and figures of speech of a 'good' description, according to traditional stylistics : an abundant use of adjectives, synesthesia, assonances and alliterations. In addition, Claes also deploys strategies of modern(ist) literature, such as abstract oneiric sequences and long-drawn-out interior monologues. Yet he introduces these modern techniques in a moderate fashion, and thus avoids disconcerting the middlebrow reader. Interior monologues, for instance, are always clearly framed by introductory formulas such as 'he thought' or 'Whitey thought to himself'. To conclude, Claes's novel also represents the act of reading itself, as a mise en abyme, and thus offers to the reader a possible readerly attitude, a model of personal engagement with the story. ${ }^{25}$ In the twelfth chapter of Whitey, the protagonist discovers in the school's lumber room an old copy of The Lion of Flanders by Hendrik Conscience, one of the most important historical novels of nineteenth-century Dutch literature. This encounter with literature serves not only as a form of escapism out of the world of law and order he lives in, but also as a source of knowledge that seems much more important than school handbooks, since it appeals to the imagination: 'Sometimes Whitey would lift his head to listen intently to the strange, mysterious noises whispering around him, and he thought he heard the resounding beat of hoofs of galloping horses, the shouts of heroes, the heavy blows of battling knights. [...] and he would see everything happen in front of his eyes, just as it has been in the past, and he was there to see it' (127-128). Whitey reenacts the depicted fights of The Lion of Flanders in real life and consequently appears to be a genuine reader, fully engaging with the story he devours. The rural discursive space of Whitey thus transforms into a novelistic scene : 'Whitey suddenly caught sight of a stray wheatsheaf propped up against the hawthorn hedge enclosing the yard, [...]. He took up his heroic stance, clamped his lance firmly under his arm, and stormed forward' (129-130).

Ernest Claes's novel Whitey can indeed be seen as a storehouse of different kinds of knowledge, which are communicated by means of a great variety of narrative techniques. Many of these lessons and narrative strategies are closely related to the generic identity of the novel as a typical instance of Dutch-language regional literature. It documents in 
detail a particular rural scene, the Belgian village Zichem, represents it as a haven of unspoiled rural identity, and instructs the reader abundantly about its geography, history, people, folklore and dialect. In addition to this explicit, reader-oriented transfer of knowledge, the novel also depicts the learning process of a childish protagonist, who functions as an implicit model for the implied readers. In spite of the anecdotal construction of the novel, the all-round formation of the protagonist is central to the novel's teleology : on the final pages of the book the picaresque hero applies for a job as a writing clerk in a well-known (and really existing) publishing house attached to the monastery in Averbode, run by Norbertine monks. Thus, against all odds, De Witte's fragmentary adventures are finally reinterpreted as a process of Bildung giving him access to culture - the farmer boy becomes a 'writer' - and religion - he treats his new masters with the utmost respect.

\section{Madelon Székely-Lulofs's Rubber : the exotic}

In contrast to Ernest Claes's regional novel, which in many ways adheres to a more traditional literary and ideological mindset, the novel Rubber by Madelon Székely-Lulofs catered to the tastes of new groups of readers by providing something of a wholly 'modern' reading experience without indulging in the stylistic excesses of the modernist novel - which was beginning to take root in Dutch literature at that time. The overall impression of modernity is created in different ways. The novel makes use of narrative techniques generally associated with modernism (such as free indirect discourse and interior monologue, and sharp film-like cuts between the scenes), and adopts a fashionable vocabulary with lots of American words and expressions. Furthermore, the action is situated in a profoundly modern world, with jazz music, the newest car models such as the Studebaker Six (produced between 1918 and 1927), middleclass tourism, the latest fashion trends, etc. As it depicts modern times in a remote and exotic place, Rubber seems far removed from the genre of the rural novel exemplified by Whitey.

However, situated in a totally different setting and preoccupied with totally different themes, a novel like Rubber appears to offer similar types of knowledge, and it even does that in quite the same (narratological) ways. Contemporary literary critics tend to describe the colonial novels of Madelon Székely-Lulofs as 'documentary fiction'. As a 'documentary' about life in the East Indies, Rubber canvasses the mores and customs of a group of planters, and in a way not dissimilar to the regional novel, this anthropology focuses on a social group whose identity primarily derives from the close ties between the characters and a specific geographical region - and the ways in which these characters 'cultivate' their surroundings. The ties that unite these men and women with the land they occupy and cultivate appear to be stronger than those forged by class membership : 'We're all planters here, and that's our social status, whether in our previous lives we have been counts or barons or carpenters' (56). In a way not dissimilar from Whitey, the documentary function goes hand in hand with the transfer of encyclopedic knowledge. The novel goes to great lengths to describe the landscape and climate of Sumatra, the different peoples living in the area, their physiognomy and customs, the colonial institutions and socio-economic organization, the kind of work performed by the planters, their social backgrounds, etc. The unknowing European reader gets, to name but one example, a step-by-step introduction to the procedure of tapping latex from rubber trees (116-120). This kind of encyclopedic knowledge is often organized in discrete textual 
chunks (paragraphs, chapters) that contribute to the stable background of the story, against which the narrative can unfold. Encyclopedic knowledge is generally considered to be a priori given information that remains unaltered by the events. Still, this kind of knowledge can be 'dramatized' in different ways and to different degrees, which is apparent from the episode about the extraction of rubber. Although the main information is given by a heterodiegetic narrator, who describes the process from a certain distance, adding generalizing comments, the focus quickly shifts to the thoughts of a Malaysian clerk working at the plant, who is keeping the books (and muses on the ever-hurried nature of the Europeans) and, finally, to a dialogue between two Europeans - the planter Frank and his superior - who are inspecting the plant and having a discussion about the maximization of the rubber profits. In this way, encyclopedic description merges with other narrative modes (interior monologue and dialogue). On top of that, it prefigures some of the main dramatic conflicts of the novel (racial conflicts, conflicts in the institutional hierarchy of the rubber company) and hints at the more implicit insight that the rubber plants are only a minute cog in the machinery of a worldwide economic system. Encyclopedic knowledge spills over into other types of knowledge.

When the protagonists of the novel - the planter Frank and his wife Marian - arrive in Sumatra, it is immediately clear that they - not unlike the reader - have to acquire a certain degree of knowledge about their new home country in order to settle and live there. Just like Whitey in the novel by Claes, the protagonists of Rubber go through a multilayered learning process. In the above-mentioned episode about the rubber industry, as part of his 'training', one of Frank's superiors instructs him about the ideal depth of the incision in the bark of the rubber tree. Yet this kind of encyclopedic knowledge is subordinated to a subtler kind of knowledge, viz. the knowledge of social norms, a certain savoir-vivre. The novel contains numerous suggestions about how to dress in certain circumstances, about how to equip a room in the East and manage a household, how to educate a child, how to behave towards superiors as well as towards inferiors, etc. These can take the form of explicit instructions (given by the narrator, or by authoritative characters); more often, however, characters (and the reader) have to induce these lessons from concrete examples (that can either be positive, or negative).

One of the first lessons Frank gets upon arriving in the colony is that planters should in all circumstances dress like planters do, viz. wear their white planter's garb, even on the occasion of a party. Early in the novel the instruction is explicitly given by a colleague of Frank : 'You didn't intend to come in a dinner jacket, did you? For Heaven's sake, man, just a white suit to-night, otherwise you won't be safe in the hands of the planters' (43). At the ensuing party, this little piece of knowledge is immediately illustrated by a real-life (negative) example : another freshman wears 'a dark blue lounge suit', for which he is ritually punished by the older planters as he is entirely painted white with whitewash and a brush (49). The lesson is clear. Dress codes, however, can change. From the moment more women settle in the Indies and wealth increases, there appear models and examples of a different kind : 'The ladies took much more care over their gowns. A native costumier had settled at Randjah who conscientiously copied frocks out of Weldon's' (129). Men wear 'white-linen "monkey" jackets' now, a fashion copied from the British Straits Settlements, which are said to be culturally influenced by the US: 'close-fitting and finished with a point at the back of the waist-with black trousers, soft shirt, stiff collar, and white waistcoat' (234). Although such information is encyclopedic and documentary 
as well, it is more overtly normative and loaded with social connotations, distinctions and values. Norms for dressing are indicative of social group identities and, hence, play a key role in the process of socialization.

This kind of social knowledge is always strongly related to ideology. The different dress codes in Rubber not only demarcate different social groups (indigenous people versus westerners, the older generation of planters versus the newer generation, the Europeans versus the Americans), but also refer to two different views on the process of colonization and the 'work' of civilization. Spanning a period of some ten years, the novel traces an evolution from a first phase - 'cultivating' the wilderness - to a second phase economically 'exploiting' the reclaimed land. The first phase is associated with the hard, physical work of (mainly male) planters, bringing some degree of civilization to inhospitable nature, making it inhabitable and productive. The second phase is associated with the establishment of a modern western society (symbolized by the arrival of women) and the economic exploitation of the work of the pioneers (symbolized by the arrival of an American manager). This second phase sees an increase of wealth and luxury, yet also testifies to a growing decadence, which in the end reveals the fundamental flaws in the western capitalist model of colonization. From that perspective, information about the way people dress is not merely accidental background information, but is crucially linked to the central ideological conflict of the novel : the uniformly white garb of the planters refers to the sense of duty and communality of the first phase, the fashionable toilets reveal something of the growing materialism and social fragmentation of the second.

Next to a social savoir-vivre, there is still a more fundamental, moral lesson to learn. The characters in Rubber are confronted with all kinds of social do's and don'ts, all kinds of explicit or implicit instructions, all kinds of models and anti-models for living, bits and pieces of knowledge, but the main issue inherent in the novel as a pedagogical project is : how can one sort them out? How to decide which norms are right and which are wrong, which are critical and which are only of secondary importance? How to construct a moral hierarchy out of bits of knowledge that are always partial and fragmentary? While encyclopedic knowledge is generally relatively stable, and a kind of given a priori to the narrative events, the moral lesson is to a certain extent the outcome of a narrative process (be it a process of Bildung or a narrative of confrontation ${ }^{26}$ ). That social knowledge and moral knowledge do not necessarily coincide is shown by the narrative trajectory of Frank and Marian. In the beginning, as newcomers to the colony, they try to adapt to the new context and circumstances, by adopting the 'exotic' social norms. When they are on leave in Holland, they have to admit that 'it was they who had changed' (254). However, from the moment that the social norms and codes of the community of planters start to change as a result of the process of 'civilization', the two protagonists are increasingly depicted as social outsiders. This is apparent from small details, such as their reluctance to participate in the car craze, which is one of the most eye-catching symptoms of the new social constellation : 'They all came in their own cars, all except Marian, who drove up in a buggy' (152). And Frank, in contrast to his friend John, refuses to play the game of politicking to gain promotion (and earn money) in the rubber business (137). From a social and material point of view, the refusal to live up to certain unspoken social codes proves disastrous, as Frank is ultimately sacked, and they are sent back to The Netherlands : 'He thought of these nine years thrown away. The dismissal that broke off his career half way' (308). However, from a moral perspective, despite - or even thanks to - the setbacks, it is particularly Marian who is able to acquire a kind of knowledge that is 
of a higher order than a merely social savoir-vivre. As an increasingly authoritative voice in the novel, she arrives at the conclusion that real value lies in an ideal of domesticity, based on the nuclear family, that transcends all geographical, social, economic (and to a certain extent even racial) circumstances : '[...] she felt a happy consciousness of the fact that this country had welded them closely together, into one unit. In this queer world, she had nobody but her husband, her child. Outside her home everything was hostile there was nothing but rivalry and envy, of status and possessions' (137).

For a novel that offers a fairly modern reading experience, this final moral lesson might sound rather traditional. The modernity of the novel lies to a certain extent in the fact that the narrative trajectory of Marian and Frank is not presented as the only legitimate option. Their process of Bildung is juxtaposed to, amongst others, the trajectory of John and Renée, another couple of planters. Renée has an affair with another planter and they eventually get divorced: René ends up living a bohemian life in Nice with her lover Ravinsky and John resumes his premarital love relation with his Japanese housekeeper. As these ways of life are not rejected, but presented as viable alternatives, there is no rigid, unequivocal moral hierarchy. From this perspective, the pedagogical aim of the novel is not so much to instruct the reader with an ultimate moral lesson, as to confront her with different options and opinions and to teach her to cope with the moral polyphony of modern society. The abundant use of narrative techniques such as interior monologue contributes to this idea of polyphony: the reader learns to know the inclinations of different characters from the inside, even to the extent that she can understand the motives of morally rather dubious characters. In the end, the moral pedagogy in Rubber, is also a pedagogy of reading: how should one accurately read a (moderately) polyphonous, but still not too discomforting modern novel ? It is perhaps not a coincidence that Renée and Ravinsky, who are from a moral perspective the most complex characters, are also most closely associated with art and literature : 'Oh God ! Did those women feel no other needs? Literature, music, the theatre.... Did they want nothing outside this eternal sameness? Ravinsky.... Yes, she could talk with him. She could talk about philosophy, religion, books' (162).

\section{Conclusion}

Whitey and Rubber both qualify as typical instances of interwar middlebrow fiction, which both met with a huge popular success in the Dutch-language literary context of the time, and yet the differences between the two books are considerable. To begin with, there is a genre difference. Whereas Whitey can be seen as an exponent of the vogue of the regional novel, or Heimatroman, which swept through Europe from the end of the nineteenth century onwards, Rubber stands in the equally long-standing tradition of the colonial novel, but which is fused with elements typical of the 1930s documentary novel. These generic differences are (not surprisingly) reflected in their respective discursive spaces : Whitey's decor is a domestic rural and local countryside, steeped in an atmosphere of homeliness, whereas the events in Rubber take place in an exotic setting, experienced as hostile and strange. On top of that, the novels differ with regard to their position in the literary field and their role in literary history. Whereas Ernest Claes's novel harks back to a highly traditional genre and fosters a conservative and nostalgic viewpoint at the level of the ideology of the story, Székely-Lulof's colonial novel integrates several techniques and topics which were considered modern, fashionable and daring at the time. While both 
novels were very popular, their position vis-à-vis legitimate, 'high' literature is different too. Claes's novel became a real classic of Flemish literature, as part of a prestigious literary oeuvre, which was quickly perceived as a bit outdated by younger generations, but nonetheless entered the literary canon as a literary monument characteristic of its time. Rubber, as an early example of the 'international bestseller', however, was a symptom of a more commercial kind of literature, which survived more because of its documentary value than as a milestone in literary histories. In this way, the books illustrate the many faces of middlebrow fiction.

Despite these unmistakable formal, thematic and institutional divergences, however, we hope to have shown that even very different middlebrow genres as the regional and the colonial novel do share important features when it comes to the transfer of knowledge. The literary representations of the regional and the colonial, as Rolf Parr has suggested, are often modelled in much the same fashion. ${ }^{27}$ Both Whitey and Rubber transfer knowledge on the extra- and the intradiegetic level. The reader follows the learning processes of one or more characters, who (sometimes explicitly) function as examples for the readers. Both novels also pass on several types of knowledge, ranging from encyclopedic and documentary knowledge, over social knowledge, moral knowledge, to aesthetic knowledge. The way in which these different types of knowledge are distributed and transferred can vary greatly, from the most explicit instructions by an authoritarian narrator, to much more subtle lessons that can be drawn from concrete positive and negative examples and experiences, from rules and codes that are a priori given to norms and insights that are gradually acquired by a process of Bildung, etc. The so-called 'pedagogical function' of middlebrow literature thus proves to be a hypernym for a network of both differentiated and interdependent epistemic functions. And even though the content of the information may vary (the regional genre deals in the first place with the rural and the recognizable, the colonial novel with the exotic and the other), the narrative devices or textual strategies by which these various types of knowledge are transferred do not always differ much. This combination of similarity and difference shows why it is of crucial importance to adopt a more comprehensive scope in middlebrow scholarship: middlebrow literature does include several subgenres, and these subgenres, however identical or heterogeneous they may appear, relate to each other on multiple levels.

One could even claim that the relations between both genres discussed here illustrate the ongoing changes in the (Dutch-language) literary system of that time, in which once immensely successful novelistic models are increasingly perceived as outdated and are gradually replaced by more up-to-date ones. In the thirties, various new novelistic novels are developed as an alternative for the existing genres of the domestic novel and the rural novel, which are increasingly perceived as powerful yet outworn spin-offs of the classical nineteenth-century realist novel. The most eye-catching innovation in this respect is undoubtedly the introduction of some variants of the international modernist novel in the Dutch literary context, yet these years also witness the rise of less highbrow and more popular alternatives. The colonial novels by Székely-Lulofs, which deal with contemporary themes and broaden the scope from a local to a more global context, are clear manifestations of these developments, but still they also clearly borrow from the 'old-fashioned' genre of the Heimatroman. In this way, the interwar middlebrow reader receives the literature she's familiar with, but with an aura of newness and difference exactly the recipe for successful middlebrow fiction. 


\section{BIBLIOGRAPHY}

Charles L. Crow (ed.). A Companion to the Regional Literatures of America. Malden : Blackwell, 2003.

Claes, Ernest. Whitey. Transl. Charles Dowsett. London : Oxford University Press, 1970.

De Geest, Dirk, Wiel Kusters, Tom Sintobin and Eveline Vanfraussen. 'Streekliteratuur in Vlaanderen en Nederland : een probleemstelling.' Spiegel der Letteren 47.2 (2005) : 89-98.

De Geest, Dirk. “Populaire' literatuur, een uitdaging voor de literatuurgeschiedenis ? Het geval Ernest Claes.' Praagse perspectieven 9. Ed. Zdenka Hrncirova, Ellen Krol, Jan Pekelder and Albert Gielen. Prague : UP, 2014. 130-131.

Draper, R.P. (ed.). The Literature of Region and Nation. New York : St. Martin's Press, 1989.

Felski, Rita. Uses of Literature. Malden : Blackwell, 2008.

Foote, Stephanie. Regional Fictions. Culture and Identity in Nineteenth-Century American Literature. Wisconsin/London : The University of Wisconsin Press, 2001.

Hinds, Hilary. 'Ordinary Disappointments : Femininity, Domesticity, and Nation in British Middlebrow Fiction, 1920-1944.' Modern Fiction Studies 55.2 (2009) : 293-320.

Hörisch, Jochen. Das Wissen der Literatur. München : Fink, 2007.

Humble, Nicola. The Feminine Middlebrow Novel, 1920s to 1950s : Class, Domesticity, and Bohemianism. Oxford/New York : Oxford University Press, 2004.

Keith, W.J. Regions of the Imagination : The Development of British Rural Fiction. Toronto : University of Toronto Press, 1988.

Klausnitzer, Ralf. Literatur und Wissen : Zugänge - Modelle - Analysen. Berlin : De Gruyter, 2008.

Lulofs, Madelon H. Rubber : The 1930s Novel which Shocked European Society. Transl. G.J. Renier and Irene Clephane. Oxford : Oxford UP, 1987.

Macdonald, Kate (ed.). The Masculine Middlebrow, 1880-1950 : What Mr Miniver Read. Basingstoke : Palgrave Macmillan, 2001.

Okker, Frank. Tumult : Het levensverhaal van Madelon Székely-Lulofs. S.l. : Olympus, 2009.

Parr, Rolf. Die Fremde als Heimat : Heimatkunst, Kolonialismus, Expeditionen. Paderborn : Konstanz University Press, 2014.

Praamstra, Olf. 'Begraven en weer opgestaan, de literaire waardering van Madelon SzékelyLulofs.' Praagse perspectieven 4. Ed. Zdenka Hrnčiřová, Ellen Krol and Wiert de Vries. Prague : UP, 2006. 47-60.

Radway, Janice. 'Research Universities, Periodical Publication, and the Circulation of Professional Expertise. On the Significance of Middlebrow Authority.' Critical Inquiry 31.1 (2004) : 203-228.

Rossbacher, Karlheinz. Heimatkunstbewegung und Heimatroman : Zu einer Literatursoziologie der Jahrhundertwende. Stuttgart : Klett, 1975.

Rubin, Joan Shelley. The Making of Middlebrow Culture. Chapel Hill/London : the University of California Press, 1992. 
Schnell, K.D.M. (ed.). The Regional Novel in Britain and Ireland, 1800-1990. Cambridge : Cambridge UP, 1998.

Shepherd, Jennifer. 'Marketing Middlebrow Feminism : Elizabeth von Arnim, the New Woman and the Fin-de-Siècle Book Market.' Philological Quarterly 84.1 (2005) : 105-131.

Sintobin, Tom. 'Wie schaft er op de woorden ?' Over de beschrijving en het beschrijvende bij Stijn Streuvels Leuven. PhD diss., 2002.

Suleiman, Susan Rubin. Authoritarian Fictions : The Ideological Novel as a Literary Genre. Princeton : Princeton UP, 1983.

Tector, Amy. 'Healing Landscapes and Evolving Nationalism in Interwar Canadian Middlebrow Fiction of the First World War.' The Masculine Middlebrow, 1880-1950. What Mr Miniver Read. Ed. Kate Macdonald. Basingstoke : Palgrave Macmillan, 2011. 104-118.

Thiesse, Anne-Marie. Écrire la France : Le mouvement littéraire régionaliste de langue française entre la Belle Époque et la Libération. Paris : PUF, 1991.

Van Boven, Erica. 'Successen en schandalen. Madelon Székely-Lulofs 1899-1958.' Schrijvende vrouwen : Een kleine literatuurgeschiedenis van de Lage Landen 1880-2010. Ed. Jacqueline Bel and Thomas Vaessens. Amsterdam : Amsterdam University Press, 2010. 47-101.

Woodmansee, Martha. The Author, Art, and the Market : Rereading the History of Aesthetics. New York : Columbia UP, 1994.

\section{NOTES}

1. Nicola Humble, The Feminine Middlebrow Novel, 1920s to 1950s. Class, Domesticity, and Bohemianism (Oxford/New York: Oxford University Press, 2004): 88.

2. Jennifer Shepherd, 'Marketing Middlebrow Feminism. Elizabeth von Arnim, the New Woman and the Fin-de-Siècle Book Market', Philological Quarterly 84.1 (2005): 111.

3. Janice Radway, 'Research Universities, Periodical Publication, and the Circulation of Professional Expertise. On the Significance of Middlebrow Authority', Critical Inquiry 31.1 (2004): 226.

4. Joan Shelley Rubin, The Making of Middlebrow Culture (Chapel Hill/London: the University of California Press, 1992).

5. Kate Macdonald (ed.), The Masculine Middlebrow, 1880-1950. What Mr Miniver Read (Basingstoke: Palgrave Macmillan: 2001): 3.

6. Humble, The Feminine Middlebrow Novel: 4.

7. Hilary Hinds, 'Ordinary Disappointments. Femininity, Domesticity, and Nation in British Middlebrow Fiction, 1920-1944', Modern Fiction Studies 55.2 (2009): 294.

8. All references are to the English translation of the novel: Ernest Claes, Whitey. Transl. Charles Dowsett (London: Oxford University Press, 1970).

9. All references are to the English translation of the novel: Madelon H. Lulofs, Rubber. The 1930s Novel which Shocked European Society. Transl. G.J. Renier and Irene Clephane (Oxford: Oxford UP, 1987).

10. Rubin, The Making of Middlebrow Culture: xi.

11. The concept of middlebrow has first been introduced as a scholarly concept in the Netherlands in special issues of TNTL (2008-2009) and Spiegel der Letteren (2012).

12. Frank Okker, Tumult. Het levensverhaal van Madelon Székely-Lulofs (s.l.: Olympus, 2009): 254; Olf Praamstra, 'Begraven en weer opgestaan, de literaire waardering van Madelon Székely-Lulofs', Praagse perspectieven 4 (Prague: UP, 2006): 254. 
13. Erica Van Boven, 'Successen en schandalen. Madelon Székely-Lulofs 1899-1958', Schrijvende vrouwen. Een kleine literatuurgeschiedenis van de Lage Landen 1880-2010, ed. Jacqueline Bel and Thomas Vaessens (Amsterdam: Amsterdam University Press, 2010): 97-101.

14. For an original perspective on this pivotal moment in the history of aesthetics, see Martha Woodmansee, The Author, Art, and the Market: Rereading the History of Aesthetics (New York: Columbia UP, 1994).

15. For an orientation, see Jochen Hörisch, Das Wissen der Literatur (München: Fink, 2007); Ralf Klausnitzer, Literatur und Wissen: Zugänge - Modelle - Analysen (Berlin: De Gruyter, 2008).

16. Rita Felski, Uses of Literature (Malden: Blackwell, 2008): 83.

17. ibid.

18. Dirk de Geest, "Populaire' literatuur, een uitdaging voor de literatuurgeschiedenis? Het geval Ernest Claes', Praagse perspectieven 9, ed. Zdenka Hrncirova, Ellen Krol, Jan Pekelder and Albert Gielen (Prague: UP, 2014): 130-131.

19. Cf. K.D.M. Schnell (ed.), The Regional Novel in Britain and Ireland, 1800-1990 (Cambridge: Cambridge UP, 1998); R.P. Draper (ed.), The Literature of Region and Nation (New York: St. Martin's Press, 1989); Charles L. Crow (ed.), A Companion to the Regional Literatures of America (Malden: Blackwell, 2003); Anne-Marie Thiesse, Écrire la France. Le mouvement littéraire régionaliste de langue française entre la Belle Époque et la Libération (Paris: PUF, 1991); Karlheinz Rossbacher, Heimatkunstbewegung und Heimatroman. Zu einer Literatursoziologie der Jahrhundertwende (Stuttgart : Klett, 1975) ; W.J. Keith, Regions of the Imagination. The Development of British Rural Fiction (Toronto: University of Toronto Press, 1988); Stephanie Foote, Regional Fictions. Culture and Identity in Nineteenth-Century American Literature (Wisconsin/London: The University of Wisconsin Press, 2001). For a (theoretical) introduction into Dutch-language regional literature, see Dirk de Geest, Wiel Kusters, Tom Sintobin \& Eveline Vanfraussen, 'Streekliteratuur in Vlaanderen en Nederland: een probleemstelling', Spiegel der Letteren 47.2 (2005): 89-98.

20. Humble, The Feminine Middlebrow Novel: 4.

21. Amy Tector, 'Healing Landscapes and Evolving Nationalism in Interwar Canadian Middlebrow Fiction of the First World War', The Masculine Middlebrow, 1880-1950. What Mr Miniver Read, ed. Kate Macdonald (Basingstoke: Palgrave Macmillan, 2011), 104-118.

22. Draper, The Literature of Region and Nation: 2.

23. In the English translation, however, these variations in linguistic register of the original version are lost.

24. Tom Sintobin, 'Wie schaft er op de woorden?' Over de beschrijving en het beschrijvende bij Stijn Streuvels (Boek 1) (Leuven, PhD diss.: 2002).

25. This finding ties in with Nicola Humble's following remark on her own middlebrow corpus: 'Reading is a fundamental trope in these novels, which demonstrate a continual preoccupation with different types of writing and different readerly relationships to it' (Humble, The Feminine Middlebrow Novel: 46).

26. Susan Rubin Suleiman, Authoritarian Fictions: The Ideological Novel as a Literary Genre (Princeton: Princeton UP, 1983).

27. Rolf Parr, Die Fremde als Heimat. Heimatkunst, Kolonialismus, Expeditionen (Paderborn: Konstanz University Press, 2014). 


\section{ABSTRACTS}

The middlebrow novel has often been characterized as a highly didactic and pedagogical literary form, that aims to combine entertainment with education and instruction. In reaction to the often rather generalizing accounts of the middlebrow novel's pedagogical function, this essay wants to sort out the different types of knowledge that can be involved and the different narrative and rhetorical means that are used to communicate these literary lessons. Focusing on two bestselling Dutch-language middlebrow novels from the interwar years - Whitey by Ernest Claes and Rubber by Madelon Székely-Lulofs - it is shown how different novelistic genres - the rural novel and the colonial novel - are almost naturally associated with different kinds of knowledge, but nevertheless display remarkably similar pedagogical strategies and techniques.

\section{INDEX}

Mots-clés: middlebrow novel, interwar literature, Dutch literature, functions of literature, literature and knowledge, literary genre, Ernest Claes, Madelon Székely-Lulofs

\section{AUTHORS}

\section{BRAM LAMBRECHT}

Bram Lambrecht is a postdoctoral research fellow at the University of Leuven. He has recently completed a PhD thesis on authorship and authority in Dutch-language middlebrow literature of the interwar years.

\section{PIETER VERSTRAETEN}

Pieter Verstraeten is a postdoctoral research fellow at the University of Groningen. He is currently involved in the NWO-funded research program Dutch Middlebrow Literature : Production, Distribution, Reception

\section{DIRK DE GEEST}

Dirk de Geest is professor of Modern Dutch Literature and Literary Theory at the University of Leuven. 